Asian Journal of Managerial Science

ISSN: 2249-6300 Vol.8 No.2, 2019, pp. 69-73

(C)The Research Publication, www.trp.org.in

\title{
Analysis on Growth of Foreign Exchange Reserves in India Since 1960-61 to 2017-18
}

\author{
R. Rajanbabu ${ }^{1}$ and A. Srilaka ${ }^{2}$ \\ ${ }^{1}$ Assistant Professor, ${ }^{2} \mathrm{PG}$ Student \\ ${ }^{1 \& 2}$ Department of Economics, Manonmaniam Sundaranar University, Tirunelveli, Tamil Nadu, India \\ E-Mail: rajaneco@ rediffmail.com
}

\begin{abstract}
This paper is primarily concerned with an analysis of the growth and trends in the foreign exchange reserves of India. It is based on secondary data and the data reliable for analysis are collected from handbook of statistics on Indian economy and the website of Reserve Bank of India. The study covers the period of 58 years from 1960-1961 to 2017-18. The collected data have been used for analysis with the help of compound growth rate. The analysis of the data reveals that foreign exchange reserves have significantly changed over the years. All the indicators noticed notable growth rate during the period under review. From the overall analysis showed that India holds adequate level of foreign exchange reserves.

Keywords: Foreign Exchange Reserves, Forex Reserves, Gold, Growth, IMF, RTP, SDRs
\end{abstract}

\section{INTRODUCTION}

Globally, there has been no exclusive definition of forex exchange reserve. Most central banks' differ among themselves in terms of coverage of items, ownership of assets and liquidity aspects. Globally central banks have accepted the definition suggested by the International Monetary Fund (Balance of Payments Manual, and Guidelines on Foreign Exchange Reserve Management, 2001). IMF defined forex exchange reserves as external assets that are readily available to and controlled by monetary authorities for direct financing of external payments imbalances, for indirectly regulating the magnitudes of such imbalances through intervention in the foreign exchange market to affect the currency exchange rate, and/or for other purposes. Since the Asian crisis (1997), foreign exchange reserve holding in Asian countries increased rapidly.

\section{A. Background}

In India, Reserve Bank of India (RBI) Act, 1934 gives power to RBI to acts as the custodian of foreign exchange reserves and manage reserves with defined objectives. RBI Act, 1934 says 'to use the currency system to the country's advantage and with a view to securing monetary stability. This implies that maximum gains for the country as a whole or economy in general could be derived in the process of reserve management, which not only provides for considerable flexibility to reserve management practice, but also warrants a very dynamic view of what the country needs and how best to meet the requirements. The term 'forex reserves' refers to value of gold holding, Special Drawing Rights (SDRs), Foreign Currency Assets (FCAs) and Reserve Position in the IMF. The most understandable reason for holding foreign exchange reserve by any country's central bank is insurance against currency crisis (Russell Green and Tom Torgerson, 2013). RBI has the same motivation and holds foreign exchange reserves basically for three motives, viz. transaction, speculation and precautionary. Transaction means managing currency flows due to international trades. Speculative motive is due to individuals and corporate trading in currency market. Precautionary motive is guided by covering unpredictable flows due to global vulnerability, deficits, return from alternative assets, etc. Moreover, forex reserves are maintained to enhance confidence in country's monetary policy and exchange rate policy, enabling orderly absorption of international money and capital flows, enhancing capacity to intervene in forex market to curb excess volatility, to balance between demand and supply of foreign currency, to preserve and improve confidence in the market especially rating agencies about the country's ability tomeet external obligations and to provide market participants confidence by backing domestic currency by external assets. However, foreign exchange reserves are not the only buffers against crisis. A few alternatives to foreign exchange reserves which are very close to reserves are currency swap line with other countries' central bank, precautionary credit line from IMF and commercial banks, sovereign wealth funds, etc.

\section{B. Reserve Management Policy in India}

Prior to 1991 payment crisis, India's approach towards foreign exchange reserve management was to maintain foreign exchange reserves to cover few months import bill. The above approach came under severe pressure from the increase in trade deficit and net invisible deficit, which led the RBI to devalue Indian rupee twice on July1 and July 3, 1991. This led to the introduction of Liberalized Exchange Rate Management System (LERMS) in March 1992 with twin objectives of building foreign exchange reserve and discouraging non-essential imports. Under this a double exchange rate system was adopted. Under LERMS, exporters could sell 60 percent of their foreign exchange earnings to authorised dealers in the open market at market determined exchange rate, while remaining 40 percent was 
to be sold compulsorily to RBI at exchange rate decided by RBI. This approach of foreign exchange reserve management underwent a paradigm shift with the adoption of the recommendations of the High Level Committee on Balance of Payments (Chairman: Dr. C. Rangarajan). The Committee recommended introduction of market determined exchange rate regime within limits; liberalization of current account transactions (i.e. full current account convertibility); encouraging capital flows from debt market to equity market; strict regulation of external commercial borrowing, especially short term debt; placed current account deficit (CAD) at 1.6 percent of GDP as ceiling, etc. The Committee also said that while determining appropriate level of foreign exchange reserves attention should be paid to payment obligation arising out of other than those for imports. The factors to be considered while determining appropriate level of foreign exchange reserves are: the need to ensure confidence to international financial community about country's ability to meet.

\section{Forex Reserves}

In simplest terms foreign exchange reserves are the foreign currencies which are held by the central bank to support liabilities on the issued currency and also a way to influence the monetary policies of the country. It includes government securities, bonds, bank notes, bank deposits and treasury bills.

Regardless of the size of the economy almost all countries in the economy hold significant foreign exchange reserves and most of them being held in U.S dollars which is the most traded currency. Other currencies in reserves are British pound sterling, euro, Chinese Yuan, and Japanese Yen. Theorists believe that holding reserves in currencies which is not immediately connected to its own is best policy. As of August 2018 China holds the largest foreign exchange reserves $\$ 3210$ billion. The holding of forex is used to back the one's domestic currency. Countries who wish to have fixed exchange rate uses forex reserves as a tool of monetary policy. Central institution has ability to exert some control over exchange rates by retaining the option to shove reserves from another currency in to the market.

\section{COMPONENTS OF FOREIGN EXCHANGE RESERVES}

\section{A. Special Drawing Rights}

"The SDR is an international reserve asset, created by the IMF in 1969 to supplement its member countries' official reserves. SDRs can be exchanged for freely usable currencies. The value of the SDR is based on a basket of five major currencies the U.S. dollar, euro, the Chinese renminbi (RMB), the Japanese yen, and pound sterling as of 2018" - IMF.

"The SDR was created by the IMF in 1969 as a supplementary international reserve asset, in the context of the Bretton Woods fixed exchange rate system. A country participating in this system needed official reserves government or central bank holdings of gold and widely accepted foreign currencies that could be used to purchase its domestic currency in foreign exchange markets, as required maintaining its exchange rate. But the international supply of two key reserve assets gold and the U.S. dollar proved inadequate for supporting the expansion of world trade and financial flows that was taking place. Therefore, the international community decided to create a new international reserve asset under the auspices of the IMF".

\section{B. Gold Reserves}

"Gold played a central role in the international monetary system until the collapse of the Bretton Woods system of fixed exchange rates in 1973. Since then, its role has diminished. But it remains an important asset in the reserve holdings of several countries, and the IMF is still one of the world's largest official holders of gold. In line with the new income model for the Fund agreed in April 2008, profits from limited gold sales were used to establish an endowment, and used to boost the IMF's concessional lending capacity to eligible low-income countries (LICs).

The IMF holds around 90.5 million ounces $(2,814.1$ metric tons) of gold at designated depositories. On the basis of historical cost, the IMF's total gold holdings are valued at SDR 3.2 billion (about $\$ 4.5$ billion), but at current market prices, their value is about SDR 80.1 billion (about $\$ 112.7$ billion). The IMF acquired its gold holdings through four main channels:

1. When the IMF was founded in 1944 it was decided that 25 percent of initial quota subscriptions and subsequent quota increases were to be paid in gold. This represents the largest source of the IMF's gold.

2. All payments of charges (interest on member countries' use of IMF credit) were normally made in gold.

3. A member wishing to acquire the currency of another member could do so by selling gold to the IMF. The major use of this provision was sales of gold to the IMF by South Africa in 1970-71.

4. Member countries could use gold to repay the IMF for credit previously extended.

The Second Amendment to the Articles of Agreement in April 1978 fundamentally changed the role of gold in the international monetary system by eliminating its use as the common denominator of the post-World War II exchange rate system and as the basis of the value of the Special Drawing Right (SDR). It also abolished the official price of gold and ended its obligatory use in transactions between the $\mathrm{IMF}$ and its member countries. It furthermore required the IMF, when dealing in gold, to avoid managing the price of gold, or establishing a fixed price."

\section{Foreign Currency Assets}

Foreign Currency Assets (FCA) that is the most important component of the RBI's foreign exchange reserve is the 
assets like US Treasury Bills bought by the RBI using foreign currencies. The FCA is the largest component of the forex reserve.

\section{Reserve Tranche Position}

International Monetary fund is financed by member's quota. Each member of the IMF is assigned a quota part of which is payable in SDR's or specified useable currencies (Reserve Assets) and part in member's own currency. The difference between a member's quota and the IMF's holding of its currency is a country's Reserve Tranche Position (RTP). The reserve tranche position of the quota can be accessed by the member at any time, whereas the rest of the member's is typically inaccessible.

\section{E. Major Countries with the Biggest Forex Reserves}

Here are the 10 countries with the largest foreign currency reserve assets as of August 2018. All reserve assets are given in billions of U.S. dollars.

TABle I Ten COUNTRIES With THE LARGEST ForeIGn CURRENCY RESERVE

\begin{tabular}{|c|l|c|}
\hline Rank & Country & $\begin{array}{c}\text { Foreign Currency Reserves } \\
\text { (in billions of U.S. dollars) }\end{array}$ \\
\hline 1 & China & $\$ 3,210.0$ \\
\hline 2 & Japan & $\$ 1,259.3$ \\
\hline 3 & Switzerland & $\$ 804.3$ \\
\hline 4 & Saudi Arabia & $\$ 501.3$ \\
\hline 5 & Russia & $\$ 460.6$ \\
\hline 6 & Taiwan & $\$ 459.9 *$ \\
\hline 7 & Hong Kong & $\$ 424.8$ \\
\hline 8 & India & $\$ 403.7$ \\
\hline 9 & South Korea & $\$ 402.4$ \\
\hline 10 & Brazil & $\$ 379.4$ \\
\hline
\end{tabular}

Source: IMF, 2018; *Central Bank of the Republic of China)

The above table I lists China's and Hong Kong's reserves separately. China has by far the largest foreign currency reserves with over two and a half times more than the second largest reserve holder, Japan. When China and Hong Kong reserves are considered together, the total is \$3.6 trillion. Asian nations dominate foreign currency reserves, accounting for six of the top 10. As of August 2018, India had foreign currency reserves of $\$ 403.7$ billion and witnessed eighth position in the world.

The United States had foreign currency reserves of $\$ 123.5$ billion as of August 2018. The United Kingdom, which did not make the list, had $\$ 187.4$ billion in foreign reserves as of August 2018. Maintaining foreign currency reserves is vital to the economic health of a nation. The top 10 nations in terms of foreign currency reserves had combined reserve assets of $\$ 8.3$ trillion as of March 2018, over half of which was accounted for by China and Hong Kong.

\section{LITERATURE REVIEW}

Charansingh (2006) India's foreign exchange reserves increased during the $1990 \mathrm{~s}$ as a result of measures introduced to liberalize capital inflows under the financial sector reforms undertaken since 1991. The Reserve Bank of India, in consultation with the government, currently manages foreign exchange reserves. As the objectives of reserve management are liquidity and safety, attention is paid to the currency composition and duration of investment so that a significant proportion can be converted into cash at short notice. The government of India intended to use a part of its foreign exchange reserves to finance infrastructure. There is no evidence that any other country has used foreign exchange reserves to finance infrastructure. The amount of foreign exchange reserves in India is modest when compared to some of the other countries in the region and it can be argued that the proposed plan may lead to more economic difficulties than anticipated benefits.

Arunachalam (2010) research work done on development over two centuries. In this research an attempt has been made to study the two booming economies of the globe with respect to their foreign exchange reserves. This study mainly based on secondary data published by respective governments and various studies done on this area. One of the paradoxes of India's hugely successful efforts since 1991 to shore up its reserves is that they are mostly in a basket of foreign currencies that are subject to volatility and disruptions.

Vanlalramsanga and Ramesh Golait (2012) found that an increase in India's foreign exchange reserve is driven mainly by the foreign-currency assets' component, while the corresponding increase in the gold reserve component did not occur for a fairly long time. Furthermore, the gold holdings in India, in terms of percentage, are relatively lower compared with increasingly sizable holdings in most of the advanced countries and even some EMEs. In general for all countries, percentage of gold holdings is seen to have been showing an increase.

Mayuresh and Ramana Raju (2013) used a time series data of the variables between 1980 and 2010 the study tries to establish a causal relationship between exchange rate and foreign exchange reserves in the Indian context. Emphasis has been laid on understanding the impact of foreign exchange reserves on the exchange rate. India has accumulated unprecedented foreign exchange reserves and synchronously has been experiencing a large depreciation in its Rupee vies avis US dollar.

Saba Abid and Neelam Jhawar (2017) analysed the trend in foreign exchange reserves and its components in India. The period of the study was defined from 2011 to 2016. The analysis of the data revealed that foreign exchange reserves have significantly changed over the years. 


\section{SIGNIFICANCE OF THE STUDY}

Foreign Exchange Reserves accumulation has gained significance both for the welfare of the nation internally and internationally. The study has its implications beneficial to policymakers, various officials of government, investors both from domestic and abroad as well as Non-resident Indians, academicians and future researchers. The study possesses academic relevance in new theoretical and practical knowledge undoubtedly. In this light of its importance, an attempt on foreign exchange reserves has been undertaken with the following specific objectives.

\section{OBJECTIVES OF THE STUDY}

1. To understand the theoretical framework of forex reserves and their significance in the economic development.

2. To analyse the growth of forex reserves in India with reference to selected components.

3. To statistically analyse the trends in the foreign exchange reserves of India.

\section{A. Hypothesis}

$H_{0}$ : India's foreign exchange reserves are expected to register better growth rate.

\section{METHODOLOGY}

The study is based on secondary data and the data reliable for analysis are collected from handbook of statistics on Indian economy and the website of Reserve Bank of India. The study covers the period of 58 years from 1960-1961 to 2017-18. The collected data have been used for analysis with the help of compound growth rate.

\section{A. Growth Model}

Growth is studied with reference to annual growth rates computed based on the compound interest rate formula adopted by the World Bank using the least square methods. The least squares growth rate ' $r$ ' is estimated by fitting a least squares linear regression trend line to the logarithmic annual values of the variable in the relevant period. More specifically, the regression equation takes the form

$$
\log X_{t}=a+b t+e_{t}
$$

Where this is the equivalent to the logarithmic transformation of the compound growth rate equation

$$
\mathrm{X}_{\mathrm{t}}=\mathrm{X}_{0}(1+\mathrm{r})^{\mathrm{t}}
$$

In these equations ' $\mathrm{X}$ ' is the variable, ' $\mathrm{t}$ ' is time period and $a=\log X_{0}$ and $b=\log (1+r)$ are the parameters to be estimated , ' $\mathrm{e}$ ' is the error term. If $b^{*}$ is the least squares estimates of ' $b$ ' then the average annual percentage growth rate ' $r$ ' is obtained as (antilog $\mathrm{b}^{*}$ ) -1 and multiplied by 100 to express it as percentage (World Development Report 1992, Oxford University Press, P.286).

\section{LIMITATIONS OF THE STUDY}

The major limitations of the study are

1. The study is made only in consideration with India and not applicable to any part of the globe.

2. The study fully depends on the secondary data, which has its own limitations.

\section{GROWTH ANALYSIS OF FOREIGN EXCHANGE RESERVES IN INDIA}

TABLE II ForEIGN EXCHANGE RESERVES IN INDIAN CURRENCY FROM

\begin{tabular}{|c|c|c|c|c|c|}
\hline 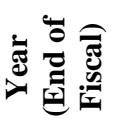 & 苨 & 苛 & 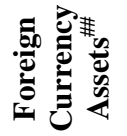 & $\underline{E}$ & 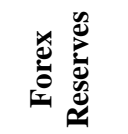 \\
\hline $1960-61$ & - & 1.18 & 1.86 & - & 3.04 \\
\hline $1965-66$ & - & 1.16 & 1.82 & - & 2.98 \\
\hline $1970-71$ & 1.12 & 1.83 & 4.38 & - & 7.33 \\
\hline $1975-76$ & 2.11 & 1.83 & 14.92 & - & 18.86 \\
\hline $1980-81$ & 4.97 & 2.26 & 48.22 & - & 55.45 \\
\hline $1985-86$ & 1.61 & 2.74 & 73.84 & - & 78.19 \\
\hline 1990-91 & 2.00 & 68.28 & 43.88 & - & 114.16 \\
\hline $1995-96$ & 2.80 & 156.58 & 584.46 & - & 743.84 \\
\hline 2000-01 & 0.11 & 127.11 & 1844.82 & - & 1972.04 \\
\hline 2005-06 & 0.12 & 256.74 & 6473.27 & 33.74 & 6763.87 \\
\hline 2010-11 & 204.01 & 1025.72 & 12248.83 & 131.58 & 13610.13 \\
\hline 2017-18 & 100.20 & 1397.40 & 25975.70 & 135.20 & 27608.50 \\
\hline C.G.R & 32.24 & 108.87 & 153.87 & 100.18 & 144.16 \\
\hline
\end{tabular}
1960-61 To 2017-18 (IN BILLION)

C.G.R.: Compound Growth Rate,

- : Negligible.

*: Foreign Currency Assets exclude investment in foreign currency denominated bonds issued by IIFC (UK), SDRs transferred by Government of India to RBI and foreign currency received under SAARC SWAP arrangement. Foreign currency assets in US dollar take into account appreciation/depreciation of non-US currencies (such as Euro, Sterling, Yen, Australian Dollar, etc.) held in reserves. Foreign exchange holdings are converted into rupees at rupee-US dollar RBI holding rates.

\#: Includes `314.63 Billion(US \$ 6699 million) reflecting the purchase of 200 metric tonnes of gold from IMF on November 3, 2009.

\#\#: Includes SDRs 3082.5 million allocated under general allocation and SDRs 214.6 million allocated under special allocation by the IMF done on August 28, 2009 and September 9, 2009, respectively. 
The table II presents the compound growth rates of selected components of foreign exchange reserves in India during the period from 1960-61 to 2017-18. In the commencement of year special drawing rights was negligible and it fluctuated over the years. Maximum of Rs.268.30 billion was witnessed in 2013-14 and subsequently it decreased to Rs.100.20 billion with 32.24 percent growth rate.

In the beginning of year, the total gold reserves in India was Rs.1.18 billion and it has increased to the highest of Rs.1397.40 billion at the end of study period. The gold reserves registered the significant growth rate of 108.87percent.In the initial period the foreign currency assets in India was Rs.1.86 billion and subsequently it increased to Rs.25,975.70 billion in over the years. For the foreign currency assets, the compound growth rate was found to be noteworthy (153.87 percent) over the periods.

In the opening year, the Reserve Tranche Position was negligible and it has increased to Rs.135.20 billion in 201718. The growth rate for Reserve Tranche Position was found to be remarkable (100.18percent).

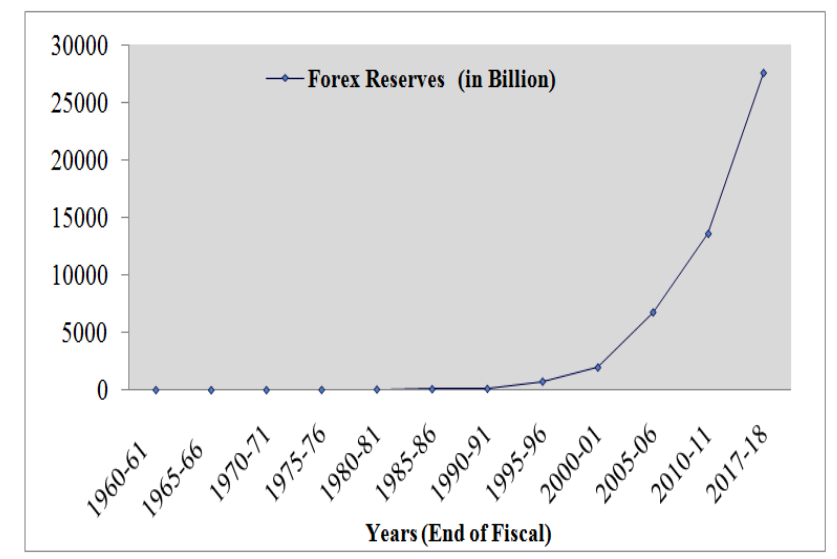

Fig. 1 Foreign Exchange Reserves in Indian Currency

\section{CONCLUSION}

The total foreign exchange reserves in India has increased from Rs.3.04 billion in 1960-61 to a maximum of Rs.27,608.50 billion in 2017-18, which reflects in the growth rate of 144.16 percent. The compound growth rate of special drawing rights, gold, foreign currency assets and reserve tranche position were order of 32.24percent, 108.87percent, 153.87 percent and100.18percent respectively. India's foreign exchange reserves increased many fold during the study period. Adequate level of foreign exchange reserves has become important parameters for determining country's ability to absorb external shocks. The analysis of the data reveals that foreign exchange reserves have significantly changed over the years. All the indicators noticed notable growth rate during the period under review. From the overall analysis showed that India holds adequate level of foreign exchange reserves.

\section{REFERENCES}

[1] Abburi Venkata Sasi Rekha \& Stella Mary. (2017). A Study of Foreign Exchange Rate Volatility on Nifty. Imperial Journal of Interdisciplinary Research (IJIR), 3(2), 1440-1443.

[2] Akshay Damani \& Vidhi Vora. (2018). An Empirical and Analytical Study of the Factors Affecting the Exchange Rate Fluctuation in India. International Journal of Innovative Studies in Sociology and Humanities, 3(3), 1-14.

[3] Alok Kumar Mishraa, Niranjan Swainb, \& D. K. Malhotrac. (2007). Volatility Spill over between Stock and Foreign Exchange Markets: Indian Evidence. International Journal of Business, 12(3), 343-359.

[4] Arunachalam, P. (2010). Foreign Exchange Reserves in India and China. African Journal of Marketing Management, 2(4), April, 69-79.

[5] Blesson James, Manjari Parashar \& Biju Sebastian. (2018). Depreciation of Indian Rupee: Causes and Impact. International Journal of Management, 8(9), 109-114.

[6] Charansingh (2006, Feb). Should India Use Foreign Exchange Reserves to Finance Infrastructure? Economic Political \& Weekly, 41(6), 517-525.

[7] Jayachandran, G. (2013). Impact of Exchange Rate on Trade and GDP for India: A Study of Last Four Decade. International Journal of Marketing, Financial Services \&Management Research, 2(9), 154170.

[8] Magda Kandil \& Ida Mirzaie. (2005). The Effects of Exchange Rate fluctuation on Output and Prices: Evidence from Developing Countries. The Journal of Developing Areas, 38(2), 189-219.

[9] Mayuresh S. Gokhale. \& J. V. Ramana Raju (2013). Causality between Exchange Rate and Foreign Exchange Reserves in the Indian Context.Global Journal of Management and Business Research Finance, 13(7), 1-7.

[10] Neeti Khullar \& Upasna Joshi Sethi (2011). Measuring the Volatility of Foreign Exchange Market in India. Research Journal of Finance and Accounting, 2(9/10), 14-26.

[11] Piyali Roy Chowdhury \& Anuradha, A. (2018). Impact of Exchange Rate Fluctuation on Stock Market Volatility - A Study to Predict the Economic Scenario in India. International Journal of Pure and Applied Mathematics, 118(18), 4309-4316.

[12] Poongothai and Kalaipriya. (2017). Foreign Exchange Reserves in India: Composition and Impact. International Journal of Applied Research, 3(9), 537-539.

[13] Prabheesh, K P., Malathy, D. \& Madhumathi, R. (2007). Demand for Foreign Exchange Reserves for India: A Co integration Approach. South Asian Journal of Management, 14(2), 36-46.

[14] Pritpal Singh Bhullar \& Manika Dhameja. (2016, Sep-Oct). Empirical Analysis of Long Run Equilibrium between Exchange Rate and Foreign Exchange Reserve - An Indian Perspective. International Journal of Management (IJM), 7(6), 89-94.

[15] Priyadarshi Dash \& Narayanan K. (2011, Jan- June). Determinants of Foreign Exchange Reserves in India: A Multivariate Cointegration Analysis. Indian Economic Review, 46(1), 83-107.

[16] Rajanbabu \& Ganesan. (2015).Production and Trade Performance of Spices Grown in India. International Research Journal of Commerce, Arts and Science, 6(9), 29-45.

[17] Rakesh, D., Raju, J. K., \& Basavangowda, K. G. (2016). An Impact of Currency Fluctuations on Indian Stock Market. International Journal of Application or Innovation in Engineering \& Management (IJAIEM), 5(6), 146-151.

[18] Saba Abid \& Neelam Jhawar. (2017, Mar-Apr). An Analysis of Foreign Exchange Reserves in India since 2001-2016. IOSR Journal of Economics and Finance (IOSR-JEF), 8(2), 70-74.

[19] Sarbapriya Ray. (2012). Foreign Exchange Reserve and its Impact on Stock Market Capitalization: Evidence from India. Research on Humanities and Social Sciences, 2(2), 46-60.

[20] Vanlalramsanga, C. \& Ramesh Golait. (2012, April). Foreign Exchange Reserves: Component-wise Analysis. Indian Journal of Finance, 6(4), 4-15. 